\title{
Neural Groove
}

National Cancer Institute

\section{Source}

National Cancer Institute. Neural Groove. NCI Thesaurus. Code C34224.

A narrow, elong ated depression on the embryonic neural plate, located between the neural folds, that, when the neural folds unite at the midline, will deepen to form the neural canal. 